\section{Public Health Genomics}

Public Health Genomics 2010;13:467-476

DOI: $\underline{10.1159 / 000293287}$
Received: February 3, 2009

Accepted after revision: October 5, 2009 Published online: March 5, 2010

\title{
Understandings of Basic Genetics in the United States: Results from a National Survey of Black and White Men and Women
}

\author{
K.D. Christensen ${ }^{a} \quad$ T.E. Jayaratne ${ }^{a} \quad$ J.S. Roberts ${ }^{a} \quad$ S.L.R. Kardia ${ }^{b} \quad$ E.M. Petty ${ }^{c}$ \\ a Department of Health Behavior and Health Education and ${ }^{\mathrm{b}}$ Department of Epidemiology, University of Michigan \\ School of Public Health, and ' Departments of Internal Medicine and Human Genetics, University of Michigan \\ Medical School, Ann Arbor, Mich., USA
}

\section{Key Words}

Gender $\cdot$ Genetic knowledge $\cdot$ Race $\cdot$ Survey $\cdot$

Understanding

\begin{abstract}
Aim: This study examined understandings of basic genetic concepts among Americans. Method: In a national telephone survey of 1,200 Americans with equal representation among Black and White men and women, subjects responded to 8 items developed by a multidisciplinary team of experts that assessed understanding of basic concepts in multiple domains, including inheritance, genetics and race, and genetics and behavior. Results: Over $70 \%$ of subjects responded correctly on items about the genetic similarity of identical twins and siblings. Less than half of subjects responded correctly on all other items. Understanding of genetics was lowest in three areas: types/locations of genes in the body ( $29 \%$ correct), a genetic basis for race ( $25 \%$ correct), and the influence of single genes on behaviors ( $24 \%$ correct). Logistic regression models controlling for age and education showed some differences by race and gender on specific items but also showed that understandings are generally similar across these groups. Conclusion: Misunderstandings about genetics are common among Black and White American men and women. Responses appear to re-
\end{abstract}

flect personal experiences, group values and interests. These findings emphasize the need for initiatives to improve the public's genetic literacy as well as a need for further investigation in this domain.

Copyright $\odot 2010$ S. Karger AG, Basel

\section{Introduction}

In light of the increasing role of genetics in various scientific endeavors, policymakers, medical professionals and academics in the U.S. have frequently voiced concern about the American public's understanding of genetics $[1,2]$. According to the National Human Genome Research Institute, 'The public must be knowledgeable to make informed decisions about participation in genomics research and to incorporate the findings of such research into their own health care' [3]. Despite this concern, few studies have empirically explored Americans' understanding of genetics, especially at the population level. What little is known suggests that the American public appears to have a poor comprehension of genetics, holding misconceptions such as the belief that genetic tests exist for intelligence and misunderstanding that the genes a father passes along determines the gender of a baby [4-6]. Such findings are

\section{KARGER}

(C) 2010 S. Karger AG, Basel

Fax +4161306 1234

E-Mail karger@karger.ch

www.karger.com
Accessible online at:

www.karger.com/phg
Kurt Christensen

Department of Health Behavior and Health Education

University of Michigan School of Public Health, 1415 Washington Heights

Ann Arbor, MI 48109-2029 (USA)

Tel. + 1734763 7726, Fax + 1734763 7379, E-Mail kdchrist@umich.edu 
consistent with results from studies of non-U.S. populations $[7,8]$.

Why should this be worrisome? The lack of basic knowledge in genetics can have important consequences in at least three ways. First, in medicine and health, misconceptions about genetic inheritance often distort people's risk perceptions and influence their willingness to seek services like genetic counseling and genetic testing that are becoming important parts of medical care [9]. The effectiveness of personalized disease management and pharmaceutical regimens tailored to individuals' genotypes will be influenced by patients' understandings of how such processes work [10]. Of additional concern is the public's response to an increasing number of genetic services with questionable utility that are available to the public without the requirement of a physician's referral, at least in the U.S. [11]. Knowledge about such services will be required for the public to be able to make safe and responsible decisions about which of these services to pursue and how to interpret results. Understanding of genetics is thus important for informed health decisionmaking and disease management, and prevention.

Second, comprehension of genetics has consequences for the public's ability to contribute to genetic policy development regarding issues like stem cell research, cloning and genetic discrimination. Public engagement is emphasized as a way to better ensure that genetic policy adequately protects the civic rights of all and promotes the most important community needs [12]. Such participation is particularly important for marginalized populations that are often excluded from policy discussions [13]. Yet, people who feel they have a poor understanding of genetics are often reluctant to engage in policy discussions [14]. More often, policymakers do not include the general public in debates about genetic policy development altogether, arguing that the ability for people to contribute meaningfully to such debates may be compromised by a misunderstanding of the subject [15]. Presumably, the more individuals understand the basics of genetic science, the more competent they will feel about expressing their opinions and becoming involved in debates about genetic policy.

Finally, history has shown how genetic science can be misused to support discriminatory and pejorative attitudes about groups deemed genetically inferior [16, 17]. Although this was clearly the case with regard to eugenics practices in the early 1900s, recent studies have linked genetic explanations for group differences to prejudicial attitudes $[18,19]$. Underlying such attitudes is often the notion that there are essential differences between cer- tain groups of individuals (e.g. those defined by ethnicity ${ }^{1}$ and gender) on particular traits (e.g. intelligence) that are due primarily to genes [20], a notion that has been rejected by many scientists [21-23]. As Prentice and Miller cogently argue [24], biological explanations for group differences reinforce the idea that individuals belonging to such groups are different types of human beings. Thus, misunderstanding how genes contribute to human traits can have problematic implications for how people stereotype and think about social groups.

\section{Studies Investigating Lay Understanding of Genetics}

Many Americans are familiar with elementary genetic language, in the sense that they have a general comprehension of terms such as genes and heredity [4]. However, people become frustrated or hesitant when trying to explain how genes work, how they are passed along or where they are located in the body $[4-6,25]$. Indeed, many people admit, when pressed, that they have little knowledge of genetics [26]. Although such claims reflect common themes in a multitude of qualitative studies, importantly, they have only recently been demonstrated in quantitative studies such as a large recent survey conducted in Western Australia [7]. Few quantitative studies explore what the American public understands and misunderstands about genetics. Moreover, published studies on how people comprehend genetics tend to focus on clinical patients or their relatives rather than the public at large; and even then, such research still shows that misunderstandings are common $[27,28]$. Finally, the few population surveys that have been conducted document that genetic knowledge is related to various demographic characteristics, but these questionnaires typically explore knowledge about the state of genomic testing rather than knowledge about fundamental genetic concepts [5, 7, 29]. In sum, population surveys assessing understanding of genetics across a range of topics are lacking.

Little work has also been done to explore lay understanding of genetics by ethnicity and gender. Such comprehension may differ in these groups, due to dissimilar experiences with or attitudes about science, health, policy, or other issues that have genetic relevance. Among educators and public health practitioners, awareness of

\footnotetext{
1 Although the terms 'race' and 'racial' occasionally appear in this paper, this does not mean that we subscribe to the view that the human species substructures into biological races. 'Ethnicity' and 'ethnic' are our preferred terms, as we believe that they more accurately describe the primary groups in our study.
} 
these differences is important as it can offer clues to better develop genetic instructional interventions that are geared to the unique interests and concerns of such groups. Of the studies exploring ethnicity and/or gender differences, some show poorer understanding among Black Americans about cancer genetics and awareness about the state of genetic technologies [29-31]. However, recent work also suggests that Black Americans are more conscious of the social implications of genetics and the way it can be used to stigmatize groups or promote racism [32]. Similarly, women are often portrayed as less knowledgeable than men at science $[33,34]$. Such speculation has not been examined empirically in the U.S. in the realm of genetics.

Multiple experts assert that educational programs to improve understanding of genetics are most effective if they build upon existing and correct conceptions about inheritance and disease [35-37]. However, with limited information about the level of genetic knowledge among the American public, educational efforts are likely to be less than optimally successful. To address this issue, we analyzed data from a large nationally representative survey of Black and White American men and women about their understanding of basic genetic concepts. Given that such concepts often have cultural bases [35, 36], and therefore are likely to vary by ethnicity and gender, the analysis was conducted separately among these groups of respondents.

\section{Methods}

\section{Procedures}

Data assessing understanding of basic genetic concepts were collected as part of a larger structured telephone survey conducted in 2001. The primary goal of the larger study was to explore genetic explanations for human traits and their impact on sociopolitical ideologies $[38,39]$. The surveys were administered by professional interviewers and averaged 40 minutes in length. Respondents were paid USD 15 for completing the survey.

\section{Sampling}

Respondents were selected using two sampling methods, both utilizing random digit dialing methods and drawing from the continental U.S. ${ }^{2}$ A main sample included 600 White and 58 Black respondents (American Association for Public Opinion Research [AAPOR] adjusted response rate $\left.\# 3=31.89^{3}\right)$. Due to the prohibitively high costs associated with obtaining Black respondents using strict random digit dialing methods, a supplemental oversample of 542 Black respondents (AAPOR adjusted response rate $\# 3=32.94^{3}$ ) was obtained within targeted population areas of higher Black density. We selected areas (telephone exchanges) for the oversample where census population data indicated a density for the Black American population of $30 \%$ or more. Ethnicity was assessed through self-report, and only individuals identifying as primarily White or Black/African American were invited to participate. The final sample of respondents (combining the main sample and the oversample) included 600 Black and 600 White Americans ranging in age from 18 to 90 years, with equal numbers of women and men.

Table 1 shows the percentage distribution and means by ethnicity and gender on selected demographic characteristics of respondents. Respondents were slightly older, slightly more educated and slightly more likely to have ever been married than individuals in the U.S. population, based on comparison with census data. To adjust for the national representativeness of the sample, we created post-stratification weights for age and education, within the ethnicity and gender of the respondent.

\section{Understanding of Genetics}

Validated scale items that measure genetic understanding are lacking. Therefore, we convened a multi-disciplinary team with expertise in human genetics, genetic epidemiology and public health to develop a set of correct or incorrect statements about genetics. Considering the arguments that important and different domains of genetic knowledge may exist [26, 36, 40, 41], items were developed to address multiple basic genetic concepts. We selected a final set of eight statements that were deemed by the expert team as most comprehensible and represented a range of topics, with relevance to health, genetic policy and gender/ race attitudes. These included items about (a) genetic inheritance among identical twins, (b) genetic inheritance in siblings, (c) genetic determination of race, (d) genetic similarity within race, (e) genetic similarity within gender, (f) genetic similarity based on physical appearance, (g) types of genes in the body, and (h) single gene influences on behavior. For the exact wording of items, see table 2.

We considered various response strategies that have been used in the past with genetic knowledge items, including 'true/false' options, multiple choice options and 'correct/not correct' options. Because science knowledge items are often threatening to respondents, this study followed work from Ondrusek et al. [42] and solicited agreement/disagreement responses to lessen this potential threat. If a statement was determined to be true according to the research team (based on their assessment of the current state of scientific knowledge), both 'strongly agree' and 'somewhat agree' were considered a correct response. Similarly, both 'strongly disagree' and 'somewhat disagree' were considered correct if the statement was deemed false. 'Neither agree nor disagree' and 'don't know' were not presented as options, as our earlier research suggested that many people would favor these answers because of their uncertainty or anxiety about giving the correct answer. However, participants who volunteered these options were marked accordingly and were categorized as 'not correct.' Depending on the item, between 1 and 12 participants answered 'nei-

\footnotetext{
2 The sampling strategy was developed and implemented by Market Strategies, Inc.

3 These response rates are in line with research conducted by the Pew Research Center for the People and the Press [56], employing standard survey practices and yielding a representative sample. For calculation of AAPOR response rate see standard definitions in [57].
} 
Table 1. Characteristics of the unadjusted sample by ethnicity/gender, reported as percentage or mean value

\begin{tabular}{|c|c|c|c|c|}
\hline & $\begin{array}{l}\text { White } \\
\text { men } \\
(\mathrm{n}=301)\end{array}$ & $\begin{array}{l}\text { White } \\
\text { women } \\
(\mathrm{n}=299)\end{array}$ & $\begin{array}{l}\text { Black } \\
\text { men } \\
(n=298)\end{array}$ & $\begin{array}{l}\text { Black } \\
\text { women } \\
(\mathrm{n}=302)\end{array}$ \\
\hline Mean age (SD) & $48(17)$ & $51(18)$ & $42(16)$ & $43(15)$ \\
\hline \multicolumn{5}{|l|}{ Education } \\
\hline Not a high school graduate & $10 \%$ & $10 \%$ & $17 \%$ & $13 \%$ \\
\hline High school graduate or equivalent & $19 \%$ & $28 \%$ & $26 \%$ & $29 \%$ \\
\hline Some college, no degree & $23 \%$ & $21 \%$ & $27 \%$ & $27 \%$ \\
\hline Associate's degree & $12 \%$ & $11 \%$ & $11 \%$ & $10 \%$ \\
\hline BA degree & $23 \%$ & $20 \%$ & $11 \%$ & $13 \%$ \\
\hline Master's degree & $8 \%$ & $8 \%$ & $5 \%$ & $7 \%$ \\
\hline Professional or doctoral degree & $5 \%$ & $1 \%$ & $3 \%$ & $1 \%$ \\
\hline \multicolumn{5}{|l|}{ Household income } \\
\hline$<20,000$ USD & $13 \%$ & $20 \%$ & $26 \%$ & $37 \%$ \\
\hline 20,000-39,999 USD & $24 \%$ & $35 \%$ & $34 \%$ & $36 \%$ \\
\hline 40,000-69,999 USD & $33 \%$ & $24 \%$ & $27 \%$ & $21 \%$ \\
\hline$\geq 70,000$ USD & $30 \%$ & $21 \%$ & $13 \%$ & $6 \%$ \\
\hline
\end{tabular}

Table 2. Percentage of participants correctly answering understanding items, for total sample and by ethnicity/gender

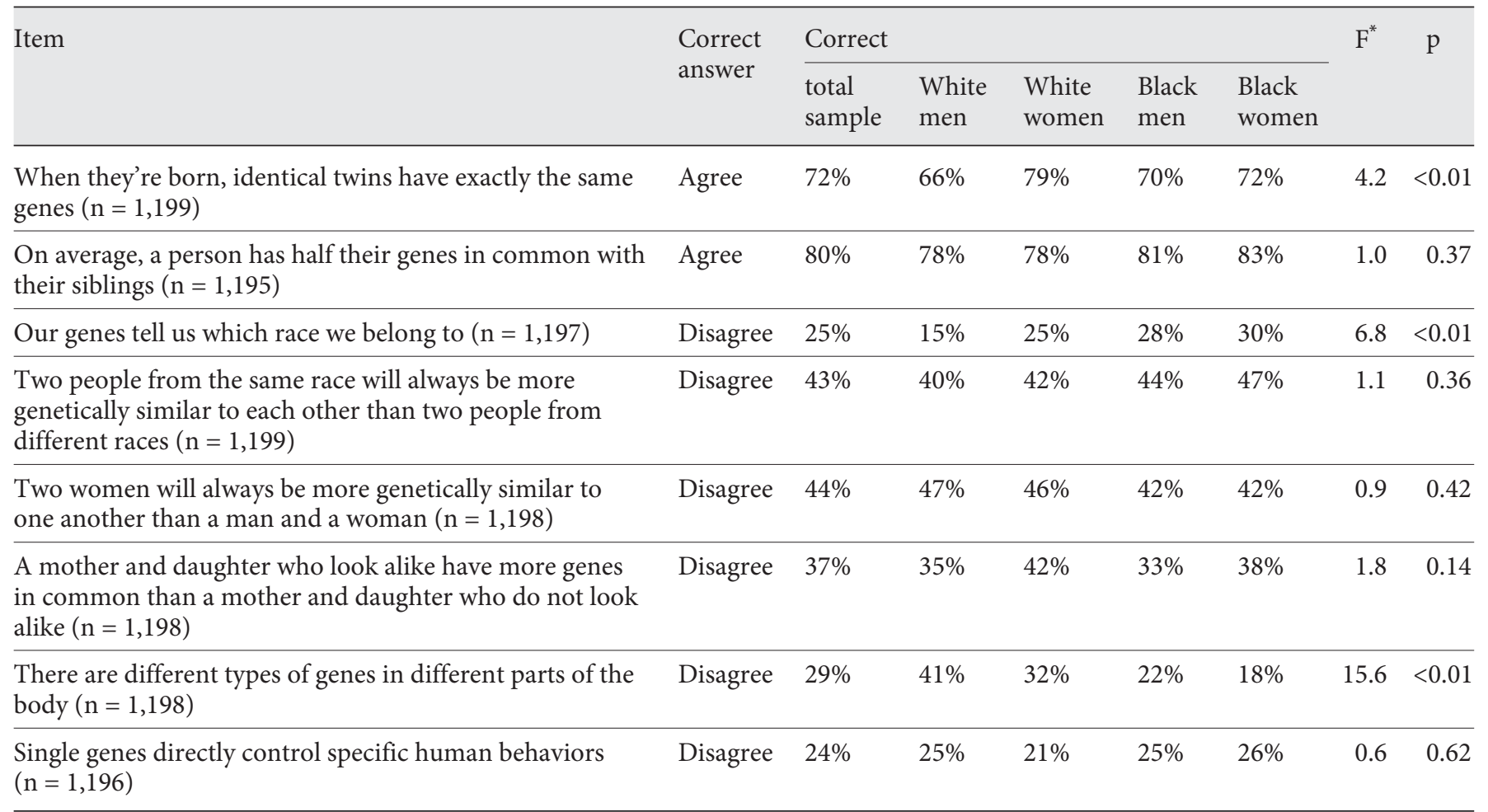

\footnotetext{
* Rao-Scott corrected F statistic [43]. Degrees of freedom of the denominator for each statistic vary from 3,534.98 to 3,547.09.
} 
ther agree nor disagree' and between 9 and 35 participants answered 'don't know.' Also, between 1 to 5 participants refused to respond to each understanding statement and were excluded from analysis of those items.

Items measuring genetic understanding were asked in two clusters in the first half of the survey. The first cluster followed items asking participants to rate how much genetics, environment and choice accounted for individual traits. The second cluster followed items asking about participants' social class attitudes.

\section{Data Analysis}

We first assessed differences by ethnicity (Black/White) and gender (male/female) combinations in the proportion of participants who correctly answered each understanding item with 2 -way tables. We then conducted logistic regression analyses to examine ethnicity and gender effects on each of the items after adjusting for age and education of the respondent. These demographic control variables were included based on their ability to predict variance in genetic understanding scales in other studies $[5,30,44]$ and to maximize the fit of logistic regression models. Education was entered in the model specific to ethnicity because education quality often varies by ethnic group [45]: one variable, for White respondents, was coded ' 1 ' for a bachelor's degree or higher, ' 0 ' otherwise; a second variable, for Black respondents, was coded similarly for education level. Data was analyzed using Stata/SE10.1 for Windows.

\section{Results}

\section{Understanding by Group}

Table 2 indicates the correct response (agree or disagree) and presents the percent of correct responses for the total sample and within each ethnicity by gender group. The large majority of participants correctly responded to the two items about Mendelian inheritance, namely, that identical twins are genetically the same (72\%) and that siblings have half their genes in common (80\%). Misunderstandings about genetics were common, however, with less than half the respondents answering any of the other items correctly. The lowest percentage of correct responses occurred for the items assessing knowledge about the types of genes in the body (29\%), genetic determination of race $(25 \%)$ and single gene influences on behavior (24\%).

Table 2 shows differences by ethnicity and gender on only three statements. On the item about inheritance among identical twins, White women reported the most correct responses (79\%) compared to the other three groups. Additionally, responses to the statement on genes determining race indicated that White men were least knowledgeable (15\%), compared with the other groups. In contrast, White men were more likely than any other group to correctly disagree with the statement about the types of genes in the body (41\%). On this statement, Black women reported the least knowledge (18\%).

Table 3 presents results from the logistic regression models that compare ethnic and gender groups while controlling for age and education specific to ethnicity. Differences by ethnicity were evident in two items. Black respondents were less likely than White respondents to answer correctly on the item assessing knowledge about the types of genes in the body but more likely to respond correctly to the item about the genetic determination of race. Among models that achieved overall statistical significance, differences by gender were evident in three items. Women indicated greater knowledge than men on statements about the genetic similarity of identical twins and the genetic determination of race. In contrast, women were less likely than men to respond correctly to the item about the types of genes in the body. In addition to these results, we found that age and education specific to ethnicity significantly predicted several of the items. In all of these cases, younger and more educated respondents tended to answer items correctly compared to older and less educated respondents.

\section{Discussion}

These data provide important empirical information about how Black and White American men and women comprehend genetics. First and foremost, our results highlight the prevalence of misunderstandings about genetics. Although a substantial majority of respondents gave the correct answer to the two statements on Mendelian genetics (inheritance), fewer than half of the respondents in any ethnic and gender group answered correctly on the other six items. On three of those six statements, specifically items regarding genetic determination of race, the types of genes in the body and single gene influences on behavior, approximately $75 \%$ of all respondents did not answer correctly. These findings suggest that many Americans are not just unsure about genetic concepts, as several previous studies indicate $[4,5]$, but also hold notable misunderstandings about basic genetic concepts.

In sum, these findings emphasize the critical need for educational initiatives to improve the genetic literacy of the American public, in part because the public's lack of basic genetic knowledge has important consequences in the areas of health, genetic policy and in the justification of prejudice. First, in the realm of health, for example, daughters who believe that they are more similar genetically to women than men may not understand that they 
Table 3. Logistic regression models of understanding items (odds ratios ${ }^{+}$)

\begin{tabular}{|c|c|c|c|c|c|c|c|c|}
\hline & \multicolumn{8}{|c|}{ Understanding item } \\
\hline & 1 & 2 & 3 & 4 & 5 & 6 & 7 & 8 \\
\hline $\begin{array}{l}\text { Blacks (referent: } \\
\text { Whites) }\end{array}$ & 1.09 & 1.18 & $\begin{array}{l}1.55^{* *} \\
\mathrm{~b}>\mathrm{w}\end{array}$ & 1.30 & 0.83 & 0.96 & $\begin{array}{l}0.49^{* *} \\
\mathrm{w}>\mathrm{b}\end{array}$ & 1.29 \\
\hline $\begin{array}{l}\text { Women (referent: } \\
\text { men) }\end{array}$ & $\begin{array}{l}1.50^{* *} \\
\mathrm{w}>\mathrm{m}\end{array}$ & 1.09 & $\begin{array}{l}1.43^{* *} \\
\mathrm{w}>\mathrm{m}\end{array}$ & 1.14 & 1.01 & $\begin{array}{l}1.31^{*} \\
\mathrm{w}>\mathrm{m}\end{array}$ & $\begin{array}{l}0.73^{*} \\
\mathrm{~m}>\mathrm{W}\end{array}$ & 0.95 \\
\hline Age & 1.00 & 1.00 & 0.99 & $\begin{array}{l}0.99^{*} \\
y>0\end{array}$ & $\begin{array}{l}0.99^{* *} \\
y>0\end{array}$ & 1.00 & 0.99 & 1.00 \\
\hline Education specific to & nicity (re & ent: le & in bachel & s degree & & & & \\
\hline $\begin{array}{l}\text { BA or higher } \\
\text { (Whites) }\end{array}$ & 1.61 & 0.75 & 1.40 & $\begin{array}{l}1.72^{* *} \\
h>1\end{array}$ & 1.39 & 1.33 & $\begin{array}{l}2.11^{* *} \\
\mathrm{~h}>1\end{array}$ & 1.55 \\
\hline $\begin{array}{l}\text { BA or higher } \\
\text { (Blacks) }\end{array}$ & 0.78 & 0.73 & $\begin{array}{l}1.57^{*} \\
\mathrm{~h}>1\end{array}$ & 1.03 & 1.12 & 0.89 & 1.25 & 0.97 \\
\hline Model fit: F-statistic & $3.47^{* *}$ & 1.61 & $5.02^{* *}$ & $3.02^{* *}$ & $2.87^{* *}$ & 1.80 & $13.99 * *$ & 1.08 \\
\hline
\end{tabular}

Items: 1 . When they're born, identical twins have exactly the same genes $(\mathrm{df}=5,1,168)$. 2 . On average, a person has half their genes in common with their siblings $(\mathrm{df}=5,1,164)$. 3. Our genes tell us which race we belong to $(\mathrm{df}=5,1,166) .4$. Two people from the same race will always be more genetically similar to each other than two people from different races $(\mathrm{df}=5,1,168)$. 5. Two women will always be more genetically similar to one another than a man and a woman $(\mathrm{df}=5,1,167)$. 6. A mother and daughter who look alike have more genes in common than a mother and daughter who do not look alike $(\mathrm{df}=5,1,167)$. 7 . There are different types of genes in different parts of the body $(\mathrm{df}=5,1,167)$. 8. Single genes directly control specific human behaviors $(\mathrm{df}=5$, $1,165)$.

$+b>\mathrm{w}$ : Black respondents more likely than White to be correct; $\mathrm{w}>\mathrm{b}$ : White respondents more likely than Black to be correct; $\mathrm{w}>\mathrm{m}$ : women more likely than men to be correct; $\mathrm{m}>\mathrm{w}$ : men more likely than women to be correct; $y>0$ : younger respondents more likely than older respondents to be correct; $\mathrm{h}>\mathrm{l}$ : respondents with higher education more likely than respondents with lower education to be correct.

${ }^{*} \mathrm{p}<0.05 ;{ }^{* *} \mathrm{p} \leq 0.01$.

can inherit susceptibility genes for breast cancer from their fathers as well as their mothers. And individuals, despite having a first-degree relative with a genetically influenced disease, may deny being at risk if for no other reason than they do not 'look like' the affected family member [25]. Thus, such misunderstanding about genetic similarity based on gender or physical appearance may have significant and negative public health outcomes. With genetics playing an increasingly important role in medical care, physicians and other health care professionals need to be aware that genetic information they share with patients may not only be confusing but may be misunderstood altogether. Second, with regard to genetic policy, individuals who lack basic genetic knowledge may have difficulty understanding or participating in dialogues regarding genetic discrimination, stem cell research or cloning or they may misjudge benefits or risks of particular genetics practices. Engagement of the public in discussions about using newborn blood spots for genedisease research, for example, may be counterproductive if the public does not understand that the genes in blood are the same as genes throughout the body. Finally, people who believe that genes determine someone's race, as was reported by a large majority of respondents, may be likely to also believe in the essential division of ethnic categories [46]. This perspective is consistent with the view that the races differ from one another in important aspects and is linked to prejudice $[18,39]$. A similar argument might be made about gender differences, where most respondents incorrectly agreed with a statement on the greater genetic similarity between two women than a man and a woman. Those who believe that behavioral aspects of gender are genetic, for example, may be more inclined to attribute the lack of women in leadership positions to inherent differences rather than social barriers [47]. 
It is noteworthy that, with regard to genes and race, respondents were much more likely to agree incorrectly with the simply worded statement that 'genes tell us which race we belong to' than the more complex statement 'two people from the same race will always be more genetically similar to each other than two people from different races.' Despite the two items having analogous scientific meaning, it is possible that the former relatively simple statement was more clearly understood by respondents compared to the latter, a more complex statement, and thus the former may have elicited more agreement. This could also be the case with regard to the four other statements (the types of genes in the body, single gene effects on behavior and the two items about inheritance), all relatively simply worded, that generated the most incorrect or correct agreement. The more even distribution of respondents who agreed and disagreed on the more complex statements may be the result of greater confusion about those items.

In addition to findings regarding genetic knowledge among all respondents, the analyses run separately by ethnicity and gender as well as results from the logistic regression showed that respondents tended to have a similar understanding about genetics overall. Exceptions that varied by ethnicity and/or gender occurred on only three items: genetic inheritance in twins, genetic determination of race and types of genes in the body. This suggests that each of these items has particular social and cultural significance.

Ethnic differences were found on two statements. First, Black respondents were more likely than White respondents to correctly disagree that genes determine race. This is consistent with findings from our previous work indicating that Black Americans are sensitive to the pejorative aspects of genetic explanations for race [32], and, among White Americans, genetic explanations for perceived race differences are associated with increased prejudice towards Blacks [39]. Second, White respondents were more likely than Black respondents to correctly disagree with the statement about types of genes in the body, an item, more than the others, that assesses basic genetic science knowledge with little ideological or social relevance. We speculate that this ethnic difference may reflect dissimilarity between Black and White Americans in the quality of education [45] or in genetic science interest [6]. With regard to the former possibility, it is interesting that education was positively associated with correct responses to the item on types of genes in the body, although this occurred only among White respondents. Education was also positively asso-

Understandings of Basic Genetics in the United States ciated with correct responses to the two statements on the genetic basis of race, although again, this differed somewhat by ethnicity.

Gender differences were found on three statements. Women were more likely than men to know about the genetic similarity of identical twins, a topic likely to be of more interest to women than men because they often serve as 'kinkeepers' of the family [26]. Women were also more likely than men to correctly disagree with the question on the genetic determination of race. Although one interpretation of this gender difference is that women are more aware than men of the ideological implications of this statement and thus disagree more strongly, studies have not consistently found gender differences in racial attitudes, at least among White respondents [48]. Alternatively, it appears that the gender effect may be partially due to the fact that only $15 \%$ of White men answered the genes determine race statement correctly, considerably less than any other ethnic/gender group. It is noteworthy that White men may have the most to gain in terms of maintaining their privileged position in the racial/gender social hierarchy by believing that group differences are genetic, and thus, natural and unchangeable $[24,38]$. However, we found no significant gender difference on the question about genetic similarity within gender, which might have been expected if this were the case. The only statement where men were more likely to answer correctly than women had to do with types of genes in the body. As with ethnic differences, this may reflect greater interest in basic genetic science among men than women [6].

Overall, these patterns of ethnic or gender differences suggest that genetic knowledge, at least on some issues, reflects personal experiences and group values and interests. In light of the fact that ethnic or gender differences appeared on only three of the eight items, however, this also suggests that much understanding or misunderstanding of genetic science may be shared across ethnic and gender groups.

\section{Limitations and Future Research}

Several limitations in our study warrant discussion. First, as noted previously, our study assessed understanding of genetics using items that have not been validated in other studies and did not undergo formal validation here. It is possible that some respondents interpreted the knowledge questions differently than intended, and a person with a very sophisticated understanding of genetics may argue about the correctness of answers on some items, despite the effort of our expert panel to judge this 
aspect of the statements. For example, the DNA of identical twins might not be exactly the same at birth because spontaneous mutations occur in the womb while unborn children are developing or due to differences in mitochondrial DNA [49]. Therefore, it is important that creation and validation of scales to assess lay understanding should be the first step in any future research on genetic literacy. Recent work has provided some instruments based on undergraduate science courses [50] and pronunciation of genetic terms [51]. These instruments may serve, along with our own measures, as the foundation for the development of a more extensive measure of genetic literacy.

A related potential limitation is the possibility of a response set to the various statements. A response set occurs when individuals offer the same answer to each question regardless of the content [52]. Survey respondents often agree to knowledge statements when they understand the item but are unsure of the answer [53], and this may partially explain why across all items, the majority of respondents agreed with the statements rather than disagreed. In our study, the fact that the only items answered correctly by a majority of respondents were two statements where the correct answer was 'agree' also suggests this possibility. However, given that both items concern knowledge of very basic genetic inheritance suggests that this is a topic that is more easily comprehended. Furthermore, adequate variability across the items and the fact that a substantial proportion of respondents provided assertive responses (i.e. 'strongly agree' or 'strongly disagree' answers, indicating some confidence) argues against a response set due to the challenging nature of the questions. Nevertheless, future work in this area needs to be sensitive to the way people answer genetic literacy questions that may be intimidating. Overall, despite these various concerns, our statements appear to have a strong degree of face validity.

\section{Conclusion}

The results from this study confirm what has been found in previous work, both in the U.S. and in other countries, that, in general, the lay public has a limited understanding of basic genetic science, although the level of knowledge varies considerably depending on the particular genetic topic. As noted in this paper, the lack of genetic information has implications for public health, genetic policy and with regard to attitudes about social class groups such as categories of gender and ethnicity. Clear- ly, there is a tremendous need for genetic education programs that address such gaps in knowledge. Institutions such as the National Human Genome Research Institute (http://www.genome.gov/Education) and the University of Utah (http://learn.genetics.utah.edu), for example, have established model programs to improve the genetic literacy of the lay public, but such efforts have been limited in scope and content to date. Our findings highlight the importance of additional work in this area.

Moreover, the pattern of results among respondents that vary by gender and ethnicity suggests that genetic knowledge that is retained reflects self and group interests or values. While this observation is not unique to genetic knowledge, as it forms the basis for teaching and motivational strategies $[54,55]$, it does emphasize the need for educators and public health practitioners to convey genetic science information in a way that will be of personal relevance and will address potential biases and misconceptions. Such efforts are critical as genetic science moves forward, generating an increasingly complex knowledge base and multifaceted social and political implications.

\section{Acknowledgments}

This study was funded by a grant awarded to Dr. Jayaratne from the Ethical, Legal, and Social Implications Research Program at the National Human Genome Research Institute (NIH grant \#R01 HG01881), with additional support from the Institute for Research on Women and Gender, the Office of the Vice President for Research and the Life Science, Values and Society Program at the University of Michigan.

References

1 Kegley JA: An ethical imperative: genetics education for physicians and patients. Med Law 2003;22:275-283.

2 Secretary's Advisory Committee on Genetics, Health and Society: A roadmap for the integration of genetics and genomics into health and society. Washington, DC, Department of Human Health \& Services, 2004.

3 Collins FS, Green ED, Guttmacher AE, Guyer MS, U. S. National Human Genome Research Institute: A vision for the future of genomics research. Nature 2003;422:835-847.

$\checkmark 4$ Lanie AD, Jayaratne TE, Sheldon JP, Kardia SL, Anderson ES, Feldbaum M, Petty EM: Exploring the public understanding of basic genetic concepts. J Genet Couns 2004; 13: 305-320. 
5 Genetics and Public Policy Center: Public awareness and knowledge; in Kalfoglou A, et al (eds): Reproductive Genetic Testing: What America Thinks. Washington, DC, Genetics and Public Policy Center, 2004, pp 7-10.

6 National Science Board: Science and Technology: public attitudes and understanding; in Science and Engineering Indicators 2008. Arlington, VA, National Science Foundation, 2008, vol 1, pp 1-47.

7 Molster C, Charles T, Samanek A, O'Leary P: Australian study on public knowledge of human genetics and health. Public Health Genomics 2009;12:84-91.

8 Human Genetics Commission: Public attitudes to human genetic information: people's panel quantitative study conducted for the Human Genetics Commission, 2001, London, UK.

9 Durant JR, Hansen A, Bauer M: Public understanding of the new genetics; in Marteau T, Richards M (eds): The Troubled Helix. New York, Cambridge University Press, 1996, pp 235-248.

10 Clark NM, Gong M, Kaciroti N: A model of self-regulation for control of chronic disease. Health Educ Behav 2001;28:769-782.

11 Offit K: Genomic profiles for disease risk: predictive or premature? JAMA 2008;299: 1353-1355.

12 Mittman IS, Secundy MG: A national dialogue on genetics and minority issues. Community Genet 1998;1:190-200.

13 Citrin T, Modell S, Gwinn MD, Bedrosian S, Ottman D, Khoury MD: Chapter 8: Genomics and public health: ethical, legal, and social issues; in Genomics and Population Health: United States 2003. 2004, The Office of Genomics and Disease Prevention, Centers for Disease Control and Prevention (CDC), Atlanta, GA, pp 851-859.

14 Jallinoja P, Aro AR: Does knowledge make a difference? The association between knowledge about genes and attitudes toward gene tests. J Health Commun 2000;5:29-39.

15 Garland MJ: Experts and the public: a needed partnership for genetic policy. Public Underst Sci 1999;8:241-254.

16 Markel H: The stigma of disease: implications of genetic screening. Am J Med 1992; 93:209-215

17 Pernick MS: Eugenics and public health in American history. Am J Public Health 1997; 87:1767-1772.

18 Keller J: In genes we trust: the biological component of psychological essentialism and its relationship to mechanisms of motivated social cognition. J Pers Soc Psychol 2005;88:686-702.
19 Yzerbyt V, Estrada C, Corneille O, Seron E, Demoulin S: Subjective essentialism in action: self-anchoring and social control as consequences of fundamental social divides; in Yzerbyt V, Judd CM, Corneille O (eds): The Psychology of Group Perception: Perceived Variability, Entitativity, and Essentialism. New York, Psychology Press, 2004, pp 101-124.

20 Bastian B, Haslam N: Psychological essentialism and stereotype endorsement. J Exp Soc Psychol 2006;42:228-235.

21 Feldman MW, Lewontin RC, King M: Race: a genetic melting-pot. Nature 2003;424:374.

22 Smedley A, Smedley BD: Race as biology is fiction, racism as a social problem is real: anthropological and historical perspectives on the social construction of race. Am Psychol 2005; 60:16-26.

$\checkmark 23$ Cooper RS, Kaufman JS, Ward R: Race and genomics. N Engl J Med 2003;348:11661170.

24 Prentice DA, Miller DT: Psychological essentialism of human categories. Curr Dir Psychol Sci 2007; 16:202-206.

25 Ponder M, Lee J, Green J, Richards M: Family history and perceived vulnerability to some common diseases: a study of young people and their parents. J Med Genet 1996; 33:485-492.

26 Emslie C, Hunt K, Watt G: A chip off the old block? Lay understandings of inheritance among men and women in mid-life. Public Underst Sci 2003;12:47-65.

27 Scheuner MT, Sieverding P, Shekelle PG: Delivery of genomic medicine for common chronic adult diseases: a systematic review. JAMA 2008;299:1320-1334.

28 Walter FM, Emery J, Braithwaite D, Marteau TM: Lay understanding of familial risk of common chronic diseases: a systematic review and synthesis of qualitative research. Ann Fam Med 2004;2:583-594.

29 Singer E, Antonucci T, Van Hoewyk J: Racial and ethnic variations in knowledge and attitudes about genetic testing. Genet Test 2004;8:31-43.

30 Donovan KA, Tucker DC: Knowledge about genetic risk for breast cancer and perceptions of genetic testing in a sociodemographically diverse sample. J Behav Med 2000;23: 15-36.

31 Lerman C, Narod S, Schulman K, Hughes C, Gomez-Caminero A, Bonney G, Gold K, Trock B, Main D, Lynch J, Fulmore C, Snyder C, Lemon SJ, Conway T, Tonin P, Lenoir G, Lynch H: BRCA1 testing in families with hereditary breast-ovarian cancer. A prospective study of patient decision making and outcomes. JAMA 1996;275:1885-1892.

- 32 Sheldon JP, Jayaratne TE, Feldbaum M, DiNardo CD, Petty EM: Applications and implications of advances in human genetics: perspectives from a group of black Americans. Community Genet 2007;10:82-92.
33 Dean C: Women in Science: The Battle Moves to the Trenches. New York Times, 12/19/2006, p F.1.

34 Summers LH: Remarks at NBER Conference on Diversifying the Science \& Engineering Workforce. Cambridge, MA, Office of the President, Harvard University, 2005. Available at http://www.president.harvard.edu/ speeches/summers_2005/nber.php.

- 35 Arcury TA, Skelly AH, Gesler WM, Dougherty MC: Diabetes meanings among those without diabetes: explanatory models of immigrant Latinos in rural North Carolina. Soc Sci Med 2004;59:2183-2193.

36 Richards M: Lay and professional knowledge of genetics and inheritance. Public Underst Sci 1996;5:217-230.

37 Richards M, Ponder M: Lay understanding of genetics: a test of a hypothesis. J Med Genet 1996;33:1032-1036.

- 38 Jayaratne TE, Gelman SA, Feldbaum M, Sheldon JP, Petty EM, Kardia SL: The perennial debate: nature, nurture, or choice? Black and White Americans' explanations for individual differences. Rev Gen Psychol 2009;13: 24-33.

39 Jayaratne TE, Ybarra O, Sheldon JP, Brown TN, Feldbaum M, Pfeffer CA, Petty EM: White Americans' genetic lay theories of race differences and sexual orientation: their relationship with prejudice toward blacks, and gay men and lesbians. Group Process Intergroup Relat 2006;9:77-94.

-40 Leyser da Rosa V, Solomon J: When science and the public meet: training for genetic counseling. Public Underst Sci 1998;7:271284.

-41 Smerecnik CM, Mesters I, de Vries NK, de Vries H: Educating the general public about multifactorial genetic disease: applying a theory-based framework to understand current public knowledge. Genet Med 2008;10: 251-258.

42 Ondrusek N, Warner E, Goel V: Development of a knowledge scale about breast cancer and heredity (BCHK). Breast Cancer Res Treat 1999;53:69-75.

43 Lee ES, Forthofer RN: Analyzing Complex Survey Data. Thousand Oaks, Sage Publications, 2006.

44 Kessler L, Collier A, Halbert C: Knowledge about genetics among African Americans. J Genet Couns 2007;16:191-200.

45 Kozol J: Savage Inequalities: Children in America's Schools. New York, Crown Publishers, 1991.

46 Yzerbyt V, Corneille O, Estrada C: The interplay of subjective essentialism and entitativity in the formation of stereotypes. Pers Soc Psychol Rev 2001;5:141-155.

47 Cole ER, Jayaratne TE, Cecchi LA, Feldbaum M, Petty EM: Vive la différence? Genetic explanations for perceived gender differences in nurturance. Sex Roles 2007;57:211-222. 
48 Hughes M, Tuch SA: Gender differences in whites racial attitudes: are women's attitudes really more favorable? Soc Psychol Q 2003; 66:384-401.

-49 Blakely EL, He L, Taylor RW, Chinnery PF, Lightowlers RN, Schaefer AM, Turnbull DM: Mitochondrial DNA deletion in 'identical' twin brothers. J Med Genet 2004;41:e19.

50 Bowling BV, Acra EE, Wang L, Myers MF, Dean GE, Markle GC, Moskalik CL, Huether CA: Development and evaluation of a genetics literacy assessment instrument for undergraduates. Genetics 2008;178:15-22.
51 Erby LH, Roter D, Larson S, Cho J: The rapid estimate of adult literacy in genetics (REAL-G): a means to assess literacy deficits in the context of genetics. Am J Med Genet A 2008; 146A:174-181.

52 Messick S: Response sets; in Sills DL (ed): International Encyclopedia of the Social Sciences. New York, Macmillan, 1968, pp 492496.

53 Aday LA: Formatting questions about knowledge and attitudes; in Designing and Conducting Health Surveys. San Francisco, Jossey-Bass, 1996, pp 243-260.

54 Schunk DH, Pintrich PR, Meece JL: Motivation in Education: Theory, Research, and Applications. Upper Saddle River, Pearson/ Merrill Prentice Hall, 2008.
55 Graham S, Taylor A: Ethnicity, gender, and the development of achievement values; in Wigfield A, Eccles JS (eds): Development of Achievement Motivation. San Diego, Academic Press, 2002, pp 121-146.

56 Pew Research Center: Survey experiment shows: Polls face growing resistance, but still representative, 2004. Available at http://peoplepress.org/reports/display.php3?ReportID $=211$.

57 American Association for Public Opinion Research: Standard definitions. Final dispositions of case codes and outcome rates for surveys, 2008. Available at http://www. a a por.org/uploads/Standard_Definitions_04_08_Final.pdf. 